\title{
EDITORIAL
}

\section{The Leiden Journal of International Law at 30}

\author{
ERIC DE BRABANDERE* AND INGO VENZKE**
}

In 2017 the Leiden Journal is celebrating its $30^{\text {th }}$ anniversary. Since the inception of the journal in I988, much has changed. This includes not only the structure, lay out, organization and publisher of the journal, but also the general environment in which the journal is published. This editorial's aim is to briefly sketch the journal's life over the past 30 years and to reflect on it.

LJIL was launched in I 988 as a journal run by students, in which a special place was also given to students' scholarly contributions. According to the journal's first editorial, contributions would 'form the nucleus of every issue'. ' The journal has gradually moved away from this focus towards the publication of articles by academics and practitioners mostly. At the same time, LJIL has not lost sight of its origins. It continues to aim at publishing innovative and original research also from younger voices. The journal is very much open to publishing contributions irrespective of the position held by the author. Next to a series of articles by established scholars, LJIL has, over the years, thus maintained the tradition of being open to younger scholars.

Along the same lines, the audience of the journal has evolved substantively. In the first editorial of the journal, the Board noted that, 'the need for scholarly writing in international law is becoming a major focus of legal education in The Netherlands (and Western Europe in general)'. ${ }^{2}$ As a student-run journal at the outset, LJIL wanted to provide a venue for some of the best efforts in that regard. At that time international law was not yet so popular a field for scholarly research - and teaching - as it is now. Few journals were exclusively dedicated to the field in the I980s. There remained a general feeling that international law was in an embryonic and dire state. ${ }^{3}$

Although one could ponder whether international law has left its embryonic state, much has changed since then in the environment in which LJIL is published. Teaching in international law ${ }^{4}$ has increased substantially in many universities, not the least because of the popularity of and students' interests in general international law and its sub-fields. To some extent, education interacts with the fragmentation

Editor-in-Chief, Professor of International Dispute Settlement, Leiden University [e.c.p.d.c.de.brabandere@ law.leidenuniv.nl].

** Editor-in-Chief, Associate Professor, University of Amsterdam [i.venzke@uva.nl].

'Editorial', (I988) I LJIL I.

Ibid.

See for instance H. Steiger, 'Probleme der Völkerrechtsgeschichte', (I987) 26 Der Staat I03.

See T. Gazzini, 'A Fresh Look at Teaching International Law-A Few Pedagogical Considerations in the Age of Communications', (20I6) 29 LJIL 97 I-8. 
of international law, with many specialized programmes bearing witness - in international criminal law or economic law, for instance. What is more, research in international law likewise, and perhaps as a consequence, has grown substantially. This is seen in the various new journals which have been created since then, either in general international law or in more specialized fields, such as international dispute settlement, international legal theory, or the use of force.

The LJIL has had the ambition to contribute to the development of research and teaching in international law by publishing pioneering research in the discipline of international law, understood holistically. Its goal ${ }^{5}$ - to remain a general international law journal - still stands today, ${ }^{6}$ which leaves room for specialized articles as well as interdisciplinary research ${ }^{7}$. In light of this ambition, however, the structure of the journal has gone through several changes over the past 30 years, in order to adapt itself to the changing audience, environment, and needs of the scholarly community.

We constantly seek to take account of developments in international law, practice and academia to adjust the Journal to these. The substance-oriented 'section' approach of LJIL, which is quite unique in the field, has been preserved, yet it has witnessed some profound modifications. Originally, LJIL published articles in four categories: 'Leading Articles', 'Current Legal Developments', 'Telders Moot Court Competition', and 'Book Reviews'. ${ }^{8}$ While the section 'Current Legal Developments' subsisted until the $25^{\text {th }}$ Volume of LJIL, since which it has been transformed into the 'International Law and Practice' section, other sections have gradually been replaced. The 'Leading Articles' section has mutated, through a section entitled 'Articles', to a section now dedicated to 'International Legal Theory', in line with the fact that the articles published as 'Articles', in fact focused on (aspects of) international legal theory. That section, as in I988, remains one of the core focal points of the journal. In that section, we have also recently launched a new series on 'International Law and its Methodology'. 9

As a consequence of the renaming of that section, 'Current Legal Developments', originally aimed at publishing 'short (approximately five pages) instructive notes covering topical international legal problems', ${ }^{\text {Io }}$ has been reframed as the 'International Law and Practice' section. It now publishes full-length articles on any field of international law, rather than short notes, which show a discernable link with how international law works in practice.

Under the editor-in-chiefships of Sam Muller and David Raič in the early I99os, and then René Lefeber, between I 996 and 2000, the Journal was marked by profound

\footnotetext{
5 At some point, however, the journal had taken the initiative to narrow its focus on 'international dispute prevention and settlement in its widest possible sense' (S. Muller and D. Raič, 'Editorial', (2009) 7 LJIL I-2). That focus has nonetheless been abandoned in subsequent years, although it remains a cornerstone of LJIL, having a special section dedicated to the International Court of Justice.

6 See Y. Radi, 'In Defence of “Generalism” in International Legal Scholarship and Practice', (2014) 27 LJIL $303-8$. T. Aalberts, 'The Politics of International Law and the Perils and Promises of Interdisciplinarity', (20I3) 6 LJIL 503-8.

8 'Editorial', (I 988) I LJIL I.

9 I. Venzke, 'International Law and its Methodology: Introducing a New Leiden Journal of International Law Series', (2015) 28 LJIL I 85-7.

ro 'Editorial', supra note 8.
} 
changes in the publication scheme. The Journal moved from two to three issues per year in I997, and then from three to four in I999. It was also during that time that the publication of LJIL, previously distributed by the Leiden Law Faculty, was transferred to an international publication partner - Kluwer Law International. In 200I, Thomas Skouteris took over as Editor-in-Chief from René Lefeber, and it was decided a couple of years later - in 2003 - to transfer the publication of LJIL to Cambridge University Press (CUP), our current publisher. In a warm cooperation with CUP we have continued to develop the journal and, in particular, its activities.

Changes have also occurred in the structure of the journal. Following the development of international courts and tribunals in The Hague, and in view of the increasing cases on the docket of the International Court of Justice, a special section 'Hague International Tribunals' was added, which also grouped articles and updates on the International Criminal Tribunal for the Former Yugoslavia. ${ }^{\text {II }}$ A specific subsection on the, then new, International Criminal Court was also added in I 998. Here again, developments in the field have prompted changes: the increase in scholarship on the law and practice of the international criminal courts and tribunals ${ }^{\mathrm{I2}}$ resulted in the creation of a special section dedicated to them. The only court still in the 'Hague International Tribunals' section is the International Court of Justice.

A bibliography on international law was also added at the end of the I990s, which is still published today.

The only section that has survived - in name - the $30^{\text {th }}$ anniversary of LJIL is the 'Book Reviews' section. At the same time, the content of what is published in this section has also witnessed much change. Besides traditional book reviews, the journal has for many years been open to larger book review essays in which reviewers can critically engage with several recently-published and related books. ${ }^{\text {I3 }}$

The Telders Moot Court Competition is no longer published in the Journal, principally because of the online access of all cases and materials related to that Moot Court Competition.

Obviously, these changes were introduced by the Editor(s)-in-Chief and Board Members of the Journal, and have been influenced by the changes in membership of the Board. From an originally student-run and exclusively Leiden-based journal, LJIL has shifted to a Board composed, in the majority, of academics and practitioners, and has over the past decade also 'opened up' to Board Members from outside the Leiden Law Faculty. At this stage, the composition of the Board reflects these changes very well. While the majority of the Board Members still are from the Leiden Law Faculty, former Editors-in-Chief Larissa van den Herik and Jean d'Aspremont put much effort into extending the membership of the Board to academics and practitioners from various law faculties in The Netherlands and elsewhere, a policy pursued by Carsten Stahn and the current Editors-in-Chief. We can now safely say that, while LJIL still

II See J.M. Amaya-Castro and T. Skouteris, 'Change of Guard', (200I) I4 LJIL I-2.

I2 See S. Vasiliev, 'On Trajectories and Destinations of International Criminal Law Scholarship', (20I5) 28 LJIL 70I-I6; E. van Sliedregt, 'International Criminal Law: Over-studied and Underachieving?', (2016) 29 LJIL I-I 2.

I3 See F. Baetens and V. Prislan, 'The Dissemination of International Scholarship: The Future of Books and Book Reviews', (2014) 27 LJIL 559-69. 
maintains a close connection with the Leiden Law Faculty, the Board's membership is representative of the geographical spread of the readership of the journal. The extension of Board membership to academics of other Faculties, in The Netherlands and outside, has without doubt strengthened the Journal.

In this respect also, the Journal presents several unique features. First, LJIL has a very decentralized management structure, in which the Board Members in charge of a specific section retain decision-making power on the publication strategy and policy of the section. The Board meets in The Hague four times per year under the direction of the Editors-in-Chief to discuss journal-wide issues and the general strategic direction the Journal takes or should take. Secondly, the practice of writing editorials, which had been abandoned somewhere in the 200os, resurfaced with the $25^{\text {th }}$ volume of the LJIL, in which former Editor-in-Chief Larissa van den Herik engaged in a discussion of the future of the LJIL 'in the age of cyberspace'. ${ }^{\text {I4 }}$ Since then, editorials have been written by all Board Members, in an exercise to offer the LJIL readership some critical thoughts on scholarship, ${ }^{15}$ the role of international law journals ${ }^{16}$ and the challenges we are facing as scholars and journal editors. ${ }^{17}$

Furthermore, in contrast to most other journals, LJIL has a standing policy that its current editors do not publish in the journal. As editors, we are dedicated to providing a venue for scholarship of the highest standards. We decidedly do not wish to use that venue for the promotion of our own voices.

Finally, briefly, the Journal has also actively developed, over the past year, its 'side' activities. ${ }^{\text {I8 }}$ Occasionally, LJIL continues to develop and sponsor special panels at international conferences. In addition, it has launched the LJIL Prize - a sort of continuation of the 'Hugo Grotius Award' launched in I988 for the 'best student contribution submitted' to the Journal. In 2015 it organized its first biannual symposium, on 'The Changing Role of Scholarship in International Law'19 and, in 2016 it has had the honour of hosting Sundhya Pahuja for the inaugural LJIL Lecture on 'The Changing Place of the Corporation in International Law'.

In the words of Niels Bohr it is difficult to make predictions, especially as they concern the future. This concerns the future of LJIL, and even more so the future of international law. Part of the celebrations of LJIL's $30^{\text {th }}$ anniversary will thus be a reflection on attempts to better understand international law's past and what that possibly does to our understanding of international law at present. We do not end our editorial with a view towards the future, other than with a wink towards our next biannual symposium in Fall 20 7 : 'The Trajectories of International Legal Histories'.

\footnotetext{
L. van den Herik, 'LJIL in the Age of Cyberspace', (20I2) 25 LJIL I-8.

I5 See, e.g., C. Stahn and E. De Brabandere, 'The Future of International Legal Scholarship: Some Thoughts on "Practice”, "Growth", and "Dissemination”, (20I4) 27 LJIL I-IO; I. Venzke, 'What Makes for a Valid Legal Argument?', (20I4) 27 LJIL 8I I-I6.

I6 See, e.g., J. d'Aspremont and L. van den Herik, 'The Public Good of Academic Publishing in International Law', (20I3) 26 LJIL I-6.

I7 See, e.g., S. Kendall, 'On Academic Production and the Politics of Inclusion', (2016) 29 LJIL 6I 7-24; C. Rose, 'International Lawyers as Public Intellectuals and the Need for More Books', (2015) 28 LJIL 393-40I.

I8 See E. De Brabandere and I. Venzke, 'The Activities of the Leiden Journal of International Law: Past, Present, and Future', (2016) 29 LJIL 285-8.

I9 A selection of the contributions has just been published in Issue 29(4).
} 